Discussion Paper No. 08-101

\title{
Patent Thickets, Licensing and Innovative Performance
}

Iain M. Cockburn, Megan J. MacGarvie, and Elisabeth Müller

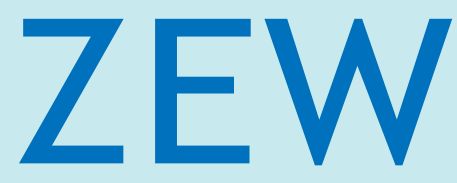

Zentrum für Europäische Wirtschaftsforschung $\mathrm{GmbH}$

Centre for European

Economic Research 
Discussion Paper No. 08-101

\title{
Patent Thickets, Licensing and Innovative Performance
}

\author{
Iain M. Cockburn, Megan J. MacGarvie, \\ and Elisabeth Müller
}

Download this ZEW Discussion Paper from our ftp server:

ftp://ftp.zew.de/pub/zew-docs/dp/dp08101.pdf

Die Discussion Papers dienen einer möglichst schnellen Verbreitung von neueren Forschungsarbeiten des ZEW. Die Beiträge liegen in alleiniger Verantwortung der Autoren und stellen nicht notwendigerweise die Meinung des ZEW dar.

Discussion Papers are intended to make results of ZEW research promptly available to other economists in order to encourage discussion and suggestions for revisions. The authors are solely responsible for the contents which do not necessarily represent the opinion of the ZEW. 


\section{Non-technical summary}

In recent years, the view of patents as a policy tool to stimulate $R \& D$ has increasingly come under criticism. The theoretical literature has shown that when research is sequential and builds upon previous innovations, stronger patents may discourage follow-on inventions and a debate has emerged over the extent to which patent "thickets" may stifle innovation. Patent thickets can be defined as "a dense web of overlapping intellectual property rights that a company must hack its way through in order to actually commercialize new technology”.

While some progress has been made in empirically characterizing thickets in terms of fragmented ownership of patent rights, there is very little evidence about how effectively the market for technology can mitigate their effects, and the extent to which this affects innovative performance. In this paper, we investigate these questions using survey data on licensing activity and innovation by German manufacturing and service firms. We use indexes of fragmentation of patent rights based on the patent portfolios of firms operating in the respective technologies of the German companies.

We find evidence that firms facing patent thickets have a higher propensity to engage in inlicensing. Therefore markets for technology may provide an effective mitigating mechanism for the defragmentation of rights. We then analyze the relationship between fragmentation and innovative performance, considering separately firms requiring access to patented technology (in-licensors) and firms that do not require this access (non-licensors). For firms that report positive expenditures on inlicensing, we find a negative relationship between fragmentation of IP rights and innovative performance as measured by introduction of new products. This is consistent with the hypothesis that, for firms that require licenses to commercialize new technology, the fragmentation of upstream property rights hampers innovation. The negative effect on product innovation is particularly strong for in-licensing firms with few patents, which suggests an important strategic role for building up a large patent portfolio in the context of fragmented property rights. 


\section{Das Wichtigste in Kürze}

In der Vergangenheit sind Patente als Anreizmechanismus für Forschung und Entwicklung in die Kritik geraten. Die theoretische Literatur hat gezeigt, dass bei auf früheren Innovationen aufbauender sequentieller Forschung stärkere Patentrechte die nachfolgenden Innovationen behindern können. Es entstand eine Debatte darüber, in welchem Ausmaß „Patentdickichte“ Innovationen erschweren. Unter Patentdickichten versteht man „ein undurchlässiges Netz von sich überschneidenden Rechten zum Schutz von geistigem Eigentum, durch das sich ein Unternehmen den Weg bahnen muss, um neue Technologien auf den Markt bringen zu können.“

Obwohl Fortschritte in der empirischen Beschreibung von Patentdickichten gemacht wurden, gibt es wenig Evidenz dafür, ob der Markt für Technologien den Einfluss von Dickichten abschwächen kann und in welchem Ausmaß Dickichte die Innovationsleistung von Unternehmen behindertn. In dieser Arbeit gehen wir diesen Fragen anhand von Daten über Lizenzaktivitäten und Innovationen von deutschen Unternehmen im verarbeitenden Gewerbe und im Dienstleistungsbereich nach. Das verwendete Fragmentierungsmaß baut auf Patentportfolios von Unternehmen auf, die in den gleichen Technologien tätig sind, wie die beobachteten deutschen Unternehmen.

Wir finden einen positiven Zusammenhang zwischen dem Ausmaß von Patentdickichten und der Wahrscheinlichkeit Patente einzulizenzieren. Märkte für Technologien sind also ein möglicher Mechanismus, um mit der Defragmentierung von Patentrechten umzugehen. Anschließend analysieren wir die Beziehung zwischen Fragmentierung und Innovationserfolg separat für Unternehmen die einen Zugang zu patentierten Technologien benötigen (lizenzierende Unternehmen) und für Unternehmen, welche keinen Zugang benötigen (nicht lizenzierende Unternehmen). Für lizenzierende Unternehmen finden wir einen negativen Zusammenhang zwischen der Fragmentierung von Patentrechten und dem Innovationserfolg gemessen als Umsatz mit neuen Produkten. Dies ist konsistent mit der Hypothese, dass Fragmentierung für Unternehmen die Lizenzen benötigen die Kommerzialisierung von neuen Produkten erschwert. Negative Auswirkungen auf Produktinnovationen sind bei lizenzierenden Unternehmen mit einer geringen Anzahl Patente besonders stark. Daraus ergibt sich eine strategische Bedeutung des Aufbaus eines großen Patentportfolios im Zusammenhang mit fragmentierten Eigentumsrechten. 


\title{
Patent Thickets, Licensing and Innovative Performance

\author{
Iain M. Cockburn*, Megan J. MacGarvie* and Elisabeth Müller**
}

November 27, 2008

\begin{abstract}
We examine the relationship between fragmented intellectual property (IP) rights and innovative performance, taking into consideration the role played by in-licensing of IP. Controlling for a variety of firm and market characteristics, we find that firms facing more fragmented IP landscapes are more likely to report expenditures on in-licensing and for those firms that do incur license costs we find a weak positive association between licensing expenditure and fragmented IP rights in the relevant technology. We also observe a negative relationship between IP fragmentation and innovative performance, but only for firms that engage in in-licensing and only for product innovation. The relationship between fragmentation and innovative performance also depends on the size of a firm's patent portfolio, which suggests an important strategic role for defensive patenting in the context of fragmented property rights.
\end{abstract}

Keywords: patent thickets, licensing, innovative performance

JEL classification: $\mathrm{O} 34, \mathrm{O} 31$

* Boston University and NBER, cockburn@bu.edu, mmacgarv@bu.edu

** ZEW Centre for European Economic Research, mueller@zew.de

Acknowledgements: We would like to thank participants of the Markets for Technology and Industry Evolution conference in Madrid and seminar participants at ZEW Mannheim and the University of Mannheim for helpful discussions. We would like to thank Bruno Cassiman for detailed comments. Elisabeth Müller gratefully acknowledges financial support from the German Science Foundation (DFG) under grant SFB/TR 15-04. This manuscript was prepared for the Markets for Technology and Industry Evolution Conference, Madrid, September 2008. 


\section{Introduction}

In recent years, the view of patents as a policy tool to stimulate R\&D has increasingly come under criticism. A theoretical literature has shown that when research is sequential and builds upon previous innovations, stronger patents may discourage follow-on inventions (Merges and Nelson 1990, Scotchmer 1991, etc.), and a debate has emerged over the extent to which patent "thickets" may stifle innovation. Defined by Shapiro (2001) as "a dense web of overlapping intellectual property rights that a company must hack its way through in order to actually commercialize new technology", patent thickets may be particularly onerous in the context of cumulative innovation and multiple blocking patents where the costs associated with patents may outweigh any positive impact on $R \& D$ incentives.

The potential for patent thickets to stifle innovation depends on the extent to which they raise the costs of innovators. In general, patents held by one firm are likely to impose some costs on other innovators, such as incremental R\&D expenditures to design around patents, or licensing fees paid for rights to use patented technology. Where there is a patent "thicket" these costs may be large enough to materially impact incentives to innovate, and in the extreme case, an "impenetrable" patent thicket may completely block inventors from accessing some technologies, or from bringing improvements to market.

In principle, the ability to negotiate licensing contracts with patent holders should allow firms to use patented inventions. Gallini (2002) notes that the stifling effects of stronger patents may be mitigated by in-licensing or other arrangements to use patented technology in downstream research projects. Indeed, Arora, Fosfuri and Gambardella (2001), Gans and Stern (2000), Gans, Hsu, and Stern (2002), and others have highlighted the role of patents and other formal IP rights in supporting a "market for technology" which provides an avenue for new entrants to realize value from innovation by licensing, entering into collaboration agreements, or selling themselves to incumbents. However, there may be circumstances under which licensing does not alleviate the thicket problem, either because licensors and licensees cannot agree on 
terms ${ }^{1}$, or because the total cost of obtaining all of the necessary licenses are prohibitive. In these circumstances, downstream innovation may be impeded in spite of attempts to gain access to upstream patented technology through licensing.

Obviously, where more licenses must be taken to "clear a path" through the thicket, total costs are likely to be higher. But an important distinction can be drawn between increases in costs that reflect larger numbers of patents to be licensed, and increases that reflect transactions costs associated with bargaining for license rights—-for example if the requisite IP is held by a large number of assignees. (Thickets are often discussed in tandem with the anti-commons problem, a concept discussed by Heller and Eisenberg (1998) in which a proliferation of upstream property rights leads to an underutilization of patented intermediate technologies and a slowdown in downstream innovation.) A number of recent papers have focused on the implications of excessive "fragmentation" of ownership of the patents necessary to commercialize a product.

In this paper, we examine the relationship between the nature of the IP "landscape" faced by a firm and the extent to which the firm participates in markets for technology via licensing. We focus on the fragmentation of rights, using the currently most common measure of thicket costs, the fragmentation index inspired by Ziedonis (2004). ${ }^{2}$ Previous work has shown that firms facing more fragmented IP landscapes have lower market values (Noel and Schankerman (2006)) and that start-up companies entering markets in which there are larger numbers of patents and assignees see the initial round of funding delayed (Cockburn and MacGarvie (2007)). ${ }^{3}$ We then examine the implications of fragmentation of IP rights for firms' innovative performance.

\footnotetext{
${ }^{1}$ Razgaitis (2006) reports that $50 \%$ or more of substantive licensing negotiations fail to result in an executed agreeement, with the leading cause of "deal failure" being inability to agree on financial terms. ${ }^{2}$ Ziedonis (2004) shows that semiconductor firms in the US patent more aggressively when the ownership of complementary patents is more highly fragmented. Von Graevenitz et al. (2008) find higher patenting activity by European firms in complex industries if patent rights are more intertwined.

${ }^{3}$ Bessen and Maskin (2000) and Bessen and Hunt (2007), have argued that more-and-stronger patent rights have induced a decline in R\&D spending in industries affected by software patents. Cockburn and MacGarvie (2007) find that software markets in which there are more patents have fewer entrants, after controlling for the characteristics of the firm and market (including the average importance of patents in the market and the stage of the product lifecycle). However, patents also play a role in stimulating entry: Cockburn and MacGarvie (2007) finds that firms holding patents related to a software market are
} 
Transactions in the market for technology, in the form of licensing agreements, are one way to "clear a path through the thicket" but may be more or less effective in "clearing a path through the thicket" depending on the nature of technology in a particular market, the nature of IP rights, and the capabilities of both licensee and licensor firms. Where IP rights are highly fragmented, licensing agreements can be a way to "reassemble" fragmented IP, but we note that in such circumstances agreements may be particularly difficult to negotiate, and are likely to be subject to more severe bargaining problems, with the total price paid by the licensor firm likely to be higher than where rights are held by fewer owners.

While some progress has been made in empirically characterizing thickets in terms of fragmented ownership of patent rights, there is very little evidence about how effectively the market for technology can mitigate their effects, and the extent to which this affects innovative performance. In this paper, we investigate these questions using survey data on licensing activity and innovation by German manufacturing and service firms, and indexes of fragmentation of patent rights based on the patent portfolios of firms operating in their technologies. Specifically, we test the hypotheses that firms facing fragmented IP landscapes will a) be more likely to engage in in-licensing to bring together the requisite pieces of upstream technology, and b) will spend more on licensing due to the larger number of parties with whom the firms must enter into contracts. We find evidence that markets for technology may provide an effective mitigating mechanism for "defragmenting" rights in the sense of a positive relationship between the degree of fragmentation of patent ownership in the industry, and these firms' propensity to engage in inlicensing. We then analyze the relationship between fragmentation and innovative performance, considering separately firms requiring access to patented technology (in-licensors) and firms that

approximately three times more likely to enter that market. Hall (2005) shows that patents have a particularly strong correlation with market value for entrants, and suggests that they play a role in helping entrants secure financing. Häussler, Harhoff, Müller (2008) and Cockburn and MacGarvie (2007) show that the number of patent applications held by a private firm speeds up the rate at which the firm obtains VC financing. 
evidently do not require this access (non-licensors). We also examine this relationship separately for product and process innovations, with the expectation that only the former should be affected by the fragmentation of IP rights. The relationship between participation in the market for technology and innovative performance is complex: overall, we find a weak positive relationship between fragmentation and innovative performance, but a quite different effect for firms that engage in in-licensing versus those who do not. For firms that report positive expenditures on inlicensing, we find a negative relationship between fragmentation of IP rights and innovative performance as measured by introduction of new products. As expected, this negative relationship is restricted to product innovation. Conversely, for firms that do not engage in inlicensing, we observe a puzzling positive relationship between fragmentation and innovative performance. While this may reflect our inability to completely control for characteristics of the product market, or for the full set of determinants of the "make versus buy" decision in acquiring technology, this finding suggests that the firm's optimal IP strategy depends on its position in the patent landscape. We also find that the negative effect on innovation is particularly strong for licensing firms with few patents, while the positive relationship between fragmentation and innovation comes largely from firms with many patents.

\section{Background and Empirical Framework}

Heller and Eisenberg (1998) pointed out that when there are too many upstream patent-holders from which an innovator must obtain licenses in order to operate, the innovator may under-invest in R\&D. Bessen (2004), in an extension of the Green and Scotchmer (1995) model of sequential innovation, shows that when innovation is cumulative and the development costs of second-round innovators are private knowledge, patent holders may engage in hold-up by not offering ex ante licenses. Lemley and Shapiro (2007) discuss the impact of the threat of holdup and royalty stacking on licensing in the context of cumulative innovation, and argue that the ability of patent holders to threaten downstream producers with injunctions can act as a tax on innovation. This 
problem is likely to be especially pernicious in the context of cumulative and complex technologies for which the downstream product potentially infringes on many patents and thus requires licenses from multiple parties (the problem of "royalty stacking"). Royalty stacking increases the amount a firm must pay to licensors in order to bring a product to market, and when the problem is severe, may reduce the rate of innovation. Royalty stacks are likely to be higher where there are more layers i.e. patent holders, and even higher where there are problems with negotiating a total price for the stack in the face of many independent owners of its components. Following Ziedonis (2004), the literature on patent thickets has focused on the "fragmentation" of property rights. Ziedonis argues that, when patents on complementary innovations are distributed widely among a large number of potential licensors, the firms requiring access to those innovations will patent more aggressively in an attempt to prevent litigation (believing that a large patent portfolio can be used to threaten a reciprocal suit). This should be particularly true when firms are highly capital-intensive. Ziedonis finds evidence in support of these hypotheses, using a measure of fragmentation based on the concentration (among patent holders) of backward citations in firms' patents. Versions of this measure of fragmentation have come to be used in a number of subsequent papers, including this one. Noel and Schankerman (2007) find that firms facing more fragmented IP landscapes have lower market values. Von Graevenitz and Siebert (2006) empirically demonstrate a negative relationship between the fragmentation of property rights and the extent of licensing, and Clark and Konrad (2008) show theoretically that fragmented property rights lead to decreased R\&D effort in patent races.

In contrast to the papers which find negative implications of fragmentation, Gerardin, Layne-Farrar, and Padilla (2006) argue that royalty stacking is rarely a problem and that several mechanisms exist (e.g. cross-licensing) to circumvent it. Lichtman (2006) argues that when the pieces of IP required to commercialize a technology are held by multiple parties, the value at stake in each negotiation is lower and therefore firms should have less reason to litigate. Galasso 
and Schankerman (2008) find evidence in support of this hypothesis, showing that firms involved in patent disputes that face fragmented IP landscapes arrive at settlements more quickly.

In this paper, we investigate the relationship between fragmentation and licensing costs, as well as the role played by licensing in mediating the relationship between fragmentation and innovative performance. Gans, Hsu and Stern (2002) argue that stronger IP rights increase both the absolute returns to innovation as well as the returns to cooperation (i.e. selling an innovation to an incumbent) relative to competition. Anand and Khanna (2000) use data on licensing announcements from the SDC database to show that variations in the strength of IPRs across industries affect the amount and nature of the licensing contracts entered into. It is likely that the pure strength of IP rights may not be the only factor affecting the participation of firms in the market for technology, but that characteristics of the "IP landscape" also play an important role. This paper focuses on the relationship between fragmentation and in-licensing. Relatively few empirical papers model the determinants of firms' expenditures on licenses. Link and Scott (2003) show that firms are more likely to license when their patents cite the patents of potential licensors. Cassiman and Veugelers (2000) relate licensing versus in-house development of technology to the external environment of the firm using CIS survey data for Belgium. Czarnitzki and Kraft (2005) study licensing expenditures by incumbents and entrants using the same innovation survey data we consider in the present paper. They find that incumbents spend more on licenses than do potential entrants. ${ }^{4}$ Czarnitzki and Kraft (2005) also find that exporters spend more on licenses than do importers and non-trading firms. Larger firms spend more on licenses, both in absolute terms and as a percentage of sales or as a percentage of innovation expenditures.

\footnotetext{
${ }^{4}$ Czarnitzki and Kraft (2005) identify entrants as the firms that rate as very important (choosing 5 on a 5point Likert scale) as a motive for innovation "the enlargement of the product portfolio outside of the main markets you are operating in." Incumbents are classified as firms that use innovation for the purposes of "securing and increasing the current market share."
} 
In this paper, we consider the relationship between the IP landscape faced by a firm and the extent of the firm's participation in the market for technology via in-licensing. We focus on the fragmentation of "upstream" IP rights, that is, whether the firm must obtain licenses from multiple parties to bring a product to market. While we do not observe the specific potential licensors, we construct a measure of fragmentation based on the citations made by the patents held by a particular firm. In brief, in an industry characterized by cumulative and complex technology, when a firm's citations are concentrated among a few entities we expect licensing costs to be lower than when citations are spread broadly across many parties. This follows the work of Ziedonis (2004), Noel and Schankerman (2006), and others (see above).

Clearly, it will be important to distinguish between large incumbents licensing new developments from start-ups or small competitors and small innovators licensing IP from upstream innovators. We examine the differences between firms with large numbers of patents and firms with few patents. We expect that the former, the "insiders", will have advantages in negotiating the terms of licenses with upstream firms, due to greater experience with the patent system, or greater bargaining power arising from holding scarce complementary assets or the ability to offer opportunities for cross-licensing. "Outsiders," with fewer of these advantages, are expected to be particularly affected by the nature of the IP landscape.

In principle, it will be important in what follows to distinguish between the impact of fragmentation of IP rights on incentives to participate in licensing from the effects of general product differentiation in the markets in which the firm competes. Arora, Fosfuri and Gambardella (2001) show that the propensity to license should be more widespread when product differentiation is lower (due to the lower rent-dissipation effects of licensing), and validate this theoretical prediction using data on product differentiation and licensing in the chemical industry. Thus, to the extent that we are unable to fully control for the degree of product differentiation, our results on licensing may be biased towards finding a negative relationship between licensing and fragmentation, which is the opposite of what we actually find. The extent of product 
differentiation is difficult to measure consistently across industries, however in an effort to control for this effect, and any more general association between market structure and licensing, we include the Herfindahl-Hirschman Index in the firm's major sector in our regressions.

\section{Data}

The analysis is based on the Mannheim Innovation Panel (MIP), an annual survey which focuses on the innovative activities of German companies. The survey is conducted annually by the Centre for European Economic Research (ZEW) on behalf of the German Federal Ministry of Education and Research. Every fourth year the survey is part of the Community Innovation Survey (CIS) conducted by Eurostat. The questionnaire follows the guidelines of the Oslo Manual for collecting innovation data (OECD and Eurostat, 1997). The target population of the MIP covers legally independent firms in Germany with at least 5 employees and covers both the manufacturing and the service sector.

Information on in-licensing of technology is available for the years 1993, 1995, 1996, 2000 and 2004. In these years information on four subgroups of innovation expenditures was asked, namely internal $R \& D$, external $R \& D$, machinery and equipment for innovative activities, and acquisition of other external knowledge. The survey provides information both on whether or not companies engaged in each of these activities as well as how much money they spent.

Patent information from the European Patent Office (EPO) is merged at the company level to the MIP. Since we use a fragmentation index at the technology level, we use the patent information to determine to which technology the majority of patent applications belongs. We therefore need to restrict the sample to companies with at least one patent application. We restrict the sample to companies with less than 1500 employees. Larger companies are often active in several technology areas. The fragmentation of ownership rights in one technology would be an imprecise indicator for the situation they face when introducing one specific product. 
Our measure of fragmentation differentiates between 30 technologies. ${ }^{5}$ The classification into 30 technologies is taken from the update of OECD (1994). For each year the current applications of all companies applying to the EPO are divided into 30 technologies, i.e. for each company up to 30 subportfolios are defined. ${ }^{6}$ For each technology the fragmentation of the subportfolios is calculated and averaged over the companies. The correction factor for number of patents in the portfolio is used. For the calculation of the measure all EPO applicants are used, i.e. there is no restriction with respect to applicant country. Only references in the " $\mathrm{X}$ " and "Y" categories are considered, i.e. only those references that are detrimental to the novelty of the patent. References that are only included to describe the technological background are omitted.

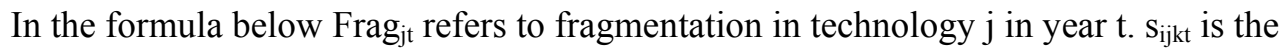
share of backward citations in company i's subportfolio of applications in technology $\mathrm{j}$ that refer to patents hold by company $\mathrm{k}$.

$$
\operatorname{Frag}_{j t}=1-\frac{1}{N}\left(\sum_{i=1}^{N} \sum_{k=1}^{K} S_{i j k t}^{2}\right)
$$

Only companies that meet a minimum size requirement are included in the calculation of the fragmentation index. Companies need to have filed at least 100 patents in the time period 1987-2002 and need to have at least three years of positive applications in a given technology area. This minimum size requirement is necessary to obtain a meaningful fragmentation measure, with very small numbers of patents in each technology, spuriously high or low values are likely to be obtained. In part this is due to that fact that at the EPO patent documents contain fewer references than at the USPTO (for our sample we find on average 4.3 references per application). This is also a reason why we prefer to use the fragmentation measure computed at the technology

\footnotetext{
${ }^{5}$ We thank Georg von Graevenitz, Dietmar Harhoff and Stefan Wagner for making the information on the fragmentation index available to us.

${ }^{6}$ Data from the database PATSTAT ("EPO Worldwide Patent Statistical Database") is used for the calculation of the fragmentation index.
} 
level as opposed to the company level. The median number of patent applications in our sample is only four and $28 \%$ of the companies have only one application, leading to a very noisy calculation of fragmentation at the company level. ${ }^{7}$

We measure innovative performance separately for product and for process innovations. The success of product innovation is measured in the MIP as the share of sales with products that are new to the market and have been introduced by the companies in the three year period preceding the survey. Fragmentation of IP rights can be expected to affect firms' abilities to innovate in a variety of ways, and we focus on this measure on the grounds that it should capture the ability of firms not just to generate new products in the sense of concepts or prototypes, but to get past any patent thicket and realize sales. For process innovations we use the percentage cost reduction that was achieved by process innovations that have been introduced by the company in the three year period preceding the survey. For many technologies, process innovations are generally more difficult to patent, infringement is more difficult to detect, and less subject to thicketing.

\section{Results}

After matching the MIP dataset to patent data, and excluding firms with more than 1500 employees, our dataset contains 1616 observations for 1034 companies. Summary statistics on our dataset are found in Tables 1-2.

As Table 1 shows, the mean firm in our data had 346 employees, 62.4 million Euro in sales, and spent 1.16 million Euro on R\&D. $56 \%$ were innovators, in the sense of realizing sales from a product that was new to the market, while $79 \%$ had introduced a product that was new to the firm. Of greatest interest for this paper, $22 \%$ reported spending money on licensing technology. The amounts spent on licensing are quite small relative to sales: in the entire sample,

\footnotetext{
${ }^{7}$ We tested the company level fragmentation measure in exploratory regressions but found mostly no relationship with the variables of interest.
} 
the average amount spent on licensing as a percentage of sales was $0.054 \%$. However, among those firms that spent anything on licensing, the ratio was $0.26 \%$. A handful of firms in these data are clearly outliers, reporting licensing expenditures as high as more than $155 \%$ of sales. While interesting in their own right, these firms are clearly engaged in distinct activities (for example, "brokering" technology), and we exclude them from this analysis. ${ }^{8}$

By contrast to the licensing data, many more firms in the sample report nonzero R\&D expenditure: $78 \%$ perform $R \& D$, (76\% spent at least 100,000 euros), and the average $R \& D$ sales ratio was $3.21 \%$. Conditional on reporting positive $R \& D$ spending the $R \& D$ sales ratio was 4.1\%. As with the licensing data, there are a handful of outliers in the dataset, with $R \& D / s a l e s$ ratios of more than $85 \%$. These are generally the same firms that report exceptionally high licensing/sales ratios and are excluded from the sample.

The fragmentation index ranges from 0.607 to 0.794 across the 30 industries in this sample. Weighted by the number of firms in each technology represented in our sample, the average value is 0.725 .

Table 2 gives simple correlations between key variables. As can be seen from the table, the raw correlation between licensing/sales and $\mathrm{R} \& \mathrm{D} / \mathrm{sales}$ is 0.11 , consistent with the idea that innovative firms are more likely to be participants in the "market for technology." The raw correlation between licensing/sales and the fragmentation index is very small, though positive, which on its face suggests only very limited use of licensing as a solution to deal with fragmentation of IP rights. However this is clearly a problem with both confounding with other effects, and the skewness of the licensing/sales variable.

Turning to the regression results, we begin by examining the relationship between licensing expenditures as a percentage of sales and IP fragmentation. The results are found in Table 3. Since the dependent variable is truncated at 0 , we use a Tobit model. We control for the

\footnotetext{
${ }^{8}$ Specifically, we drop observations where licensing/sales $>2.27 \%$. We also drop some observations with very large absolute amounts of licensing expenditure.
} 
firms' $R \& D /$ sales ratio, the patent stock of the firm normalized by employment, firm size (the log of the number of employees), log of total patent applications per year at the EPO in the relevant technology area, the Herfindahl index of sales in the firm's product market as provided by the German Monopoly Commission, the industry-average of the reported effectiveness of patents "to obtain or improve competitive strength" (taken from the MIP survey of the year 1992), the age of the firm, and a dummy for East German firms, as well as a full set of dummies for the survey year and primary industry of the firm.

The results in column 1 of Table 3 show that fragmentation is positively and significantly related to licensing expenditures as a percentage of sales. We also estimate a probit model of the probability of licensing as well as a Tobit restricted to positive observations on licensing as a percentage of sales. In the latter specification, we observe a positive but insignificant effect of fragmentation, while the effect in the Probit model remains statistically significant at the 5\% level. We thus obtain evidence that fragmentation is associated with an increase in the probability of licensing but we cannot reject the hypothesis that it is unrelated to the total cost of licensing (though the point estimate is positive). Using the probit specification we find that an increase in fragmentation of one standard deviation increases the probability of in-licensing by 3.0 percentage points. This is a sizable effect given that the probability of in-licensing is $22 \%$ in the sample. ${ }^{9}$

The $\mathrm{R} \& \mathrm{D} /$ sales ratio is positively and significantly associated with licensing, as is the index for patent protection, consistent with the predictions of Gans, Hsu, and Stern (2002) and Arora, Fosfuri and Gambardella (2001) that stronger IP rights are associated with more licensing. Larger firms spend more on licensing as a percentage of sales, but age is insignificantly related to licensing expenditures.

\footnotetext{
${ }^{9}$ A related finding is present in Nagaoko (2008), which uses a survey of Japanese inventors. As the number of patents required to commercialize a technology increases, the propensity of firms to engage in licensing increases.
} 
We then turn to the question of whether fragmentation of IP rights affects innovative performance. We focus on firms' reported share of sales coming from products new to the market as our measure of performance. Table 4 contains results from a Tobit regression in which the dependent variable is the share of sales coming from products new to the market (our measure of success with product innovativs). The sample size is slightly smaller at 1343 observations since information on the dependent variable is missing for some companies. We control for the patent stock of the firm, innovation intensity (total expenditure on innovation per employee), age and size of the firm, and industry characteristics such as the Herfindahl index of sales and importance of patent protection. Overall, the estimated relationship between fragmentation and innovative performance is positive and marginally significant. Importantly, however, this finding is driven by firms that do not license, because when we restrict attention to firms that report nonzero licensing expenditure, we observe a negative and statistically significant relationship between fragmentation and innovative performance (as captured by this measure). This is consistent with the hypothesis that, for firms that require licenses to commercialize new technology, the fragmentation of upstream property rights hampers innovation. A one standard deviation increase in fragmentation reduces the share of sales with new products by 2.2 percentage points for licensees and increases the share by 1.4 percentage points for companies without inlicensing activity. Relative to the mean of the share of sales this translates into a reduction of $20.0 \%$ and an increase of $16.7 \%$ respectively. Estimated coefficients for other explanatory variables conform to expectations: we find positive and significant associations between innovative performance and innovation expenditure per employee and stock of granted patents, and a negative association between innovative performance and firm size (larger firms are more likely to have a larger share of sales from previous generations of products. ${ }^{10}$ To dig

\footnotetext{
${ }^{10}$ In regressions not reported here, we also investigated the relationship between fragmentation and strategic patenting. We regressed the firm's patent stock on the fragmentation index and a set of control variables. However, in contrast to the work of Ziedonis, we do not observe any significant relationship between the firm's patent stock and the degree of IP fragmentation.
} 
deeper into these findings, columns 4-7 of Table 4 present results comparing the innovative performance of "outsiders" (firms with fewer than five patents) and "insiders" (firms with five or more patents). We chose the median number of patent applications of four to divide into the two subsamples. These regressions reveal that the negative relationship between fragmentation and innovation is strongest for licensing firms with fewer patents, while the positive effect of fragmentation among non-licensors is greater for firms with more patents. This result is intriguing, as it is consistent with the hypothesis that in-licensing firms with smaller patent portfolios are more susceptible to the type of hold-up associated with patent thickets, while firms with large portfolios that do not need to license upstream technology may actually benefit from the existence of patent thickets.

In Table 5 we present results from a similar regression in which we instead use as dependent variable an indicator of the firm's success at process innovations - the amount of process-innovation-driven unit cost reductions. These regressions serve as an important robustness check. We do not expect to observe a significant negative relationship between fragmentation and this dependent variable, because the threat of hold-up from upstream patentholders should not impinge upon firms' abilities to generate cost reductions through process innovations. Here, we see a similar pattern when we look at firms that do not license: a positive and significant relationship between fragmentation and process innovation. However, in contrast to the findings on innovative sales, we find a positive and statistically insignificant relationship between fragmentation and innovation for licensees.

In Table 6, we present results from regressions that include the interaction of fragmentation and innovation expenditure. The coefficient on this interaction term is negative and significant for licensees. This implies that the positive relationship between innovation expenditures and innovative sales is mitigated when the firm faces a fragmented IP landscape. One possible interpretation for these results may be that higher fragmentation requires firms to spend more on innovation in duplicative "inventing around" patented prior art. An alternative 
interpretation is that innovation expenditure is less effective in producing innovative sales when firms develop products for markets characterized by fragmented IP.

\section{Discussion and Conclusion}

We have examined the relationship between fragmented IP rights and innovative performance, taking into consideration the role played by in-licensing of IP. We find that firms facing more fragmented IP landscapes have higher licensing costs, which is consistent with a "royalty stacking" story, and/or a relationship between bargaining problems and fragmented ownership of rights. Note that this is not a reflection of a linear relationship between the number of licenses acquired and in-licensing expenditures: the fragmentation index captures a very different aspect of the patent landscape. We also observe a negative relationship between IP fragmentation and performance with product innovations, but only for firms that engage in in-licensing. This result is perhaps surprising, since it suggests that even though firms are able to arrive at licensing agreements, they generate fewer sales from innovative products as a share of total sales than firms that must bargain with fewer potential licensors.

The relationship between fragmentation and innovative performance also depends on the size of a firm's patent portfolio. That is, the relationship between fragmentation and innovative performance is most pronouncedly negative among licensing firms that have fewer than five patents, and it is most pronouncedly positive among non-licensors with five or more patents. This finding is suggestive of the strategic importance of defensive patenting in the context of fragmented property rights - firms seem to be able to reduce the impact of fragmentation on performance by building up a stock of patents. This appears to be consistent with Ziedonis's hypotheses about the benefits of defensive patenting when facing fragmented ownership of rights to complementary technologies.

Some limitations of our study include the fact that companies without any patents are excluded from our sample. While we could not include non-patenters because of the way we 
construct our fragmentation index (based on the technology area in which the firm has the majority of its patents), non-patenters may also face problems due to fragmentation of IP rights. Indeed, these may be even more severe: given our argument that firms with smaller patent portfolios are more negatively affected by fragmentation, we might expect firms with no patents to be even more negatively affected, and thus our findings may be viewed as an underestimate of the effect for these firms. Another limitation of our data is that we cannot observe cross-licensing agreements in which no licensing fees are paid. To the extent that firms use a mixture of licensing contracts with monetary compensation and cross-licenses, our findings about the importance of patent portfolio size could reflect the use of firms' patent portfolios in cross-licensing to deal with the fragmentation problem.

Notwithstanding these limitations, we believe that this research highlights the complex role played by market structure in the market for technology, and points to a number of interesting directions for further investigation. While licensing transactions offer a means of accessing technology and product markets in the face of thickets of blocking patents, the economic efficiency of this mechanism is poorly understood, and it may have important limits. In particular, there may be important non-linearities in the relationship between fragmentation of IP rights, incentives to license, and costs of innovating. For example, in the extreme case of very highly fragmented patent landscapes, the presence of too many licensors and too many patents may led to insuperable bargaining problems that render licensing impractical or irrelevant, bringing about a complete breakdown of the price mechanism in the market for technology. Here we may expect to see quite different solutions emerge, with very different IP strategies used by market participants. 
Table 1: Summary statistics

\begin{tabular}{|l|c|c|c|c|c|}
\hline Variable & Mean & Median & Std. dev & Min & Max \\
\hline Employees & 346.4 & 260 & 302.9 & 2 & 1500 \\
\hline Age of firm (years) & 20.9 & 14 & 22.8 & 0 & 175 \\
\hline Sales (in million EUR) & 62.43 & 38.45 & 92.71 & 0.19 & 1240 \\
\hline R\&D (in million EUR) & 1.16 & 0.35 & 2.10 & 0 & 26.04 \\
\hline Fragmentation & 0.725 & 0.729 & 0.028 & 0.607 & 0.794 \\
\hline Dummy licensing & 0.219 & 0 & 0.413 & 0 & 1 \\
\hline Licensing/sales (in \%) & 0.0542 & 0 & 0.198 & 0 & 2.12 \\
\hline $\begin{array}{l}\text { Licensing/sales conditional on } \\
\text { licensing>0 (in \%) }\end{array}$ & 0.262 & 0.123 & 0.367 & 0.0002 & 2.12 \\
\hline $\begin{array}{l}\text { Share of sales from products new } \\
\text { to the market (in \%) }\end{array}$ & 8.98 & 3 & 15.8 & 0 & 100 \\
\hline $\begin{array}{l}\text { Cost reduction due to process } \\
\text { innovations (in \%) }\end{array}$ & 5.01 & 2 & 7.47 & 0 & 61 \\
\hline R\&D/sales (in \%) & 3.21 & 1.31 & 5.91 & 0 & 63.6 \\
\hline $\begin{array}{l}\text { R\&D/sales conditional on } \\
\text { R\&D>0 (in \%) }\end{array}$ & 4.10 & 2.11 & 6.40 & 0.001 & 63.6 \\
\hline $\begin{array}{l}\text { Innovation exp. (in '000 } \\
\text { EUR)/employees }\end{array}$ & 7.88 & 4.26 & 14.99 & 0 & 261 \\
\hline Patent stock of firm & 10.36 & 4 & 20.25 & 1 & 236 \\
\hline $\begin{array}{l}\text { Patents at technology level (in } \\
\text { '000) }\end{array}$ & 3.05 & 2.77 & 1.48 & 0.275 & 12.28 \\
\hline Index patent protection & 2.67 & 2.62 & 0.464 & 1 & 5 \\
\hline $\begin{array}{l}\text { Herfindahl index of sales in 3- } \\
\text { digit industry }\end{array}$ & 45.3 & 14.67 & 66.7 & 0.88 & 416.1 \\
\hline Dummy Eastern Germany & 0.132 & 0 & 0.338 & 0 & 1 \\
\hline
\end{tabular}

Table 2: Correlation table

\begin{tabular}{|l|c|c|c|}
\hline & Licensing/sales & R\&D/sales & Fragmentation \\
\hline Licensing/sales & 1.00 & & \\
\hline R\&D/sales & $0.111^{* * *}$ & 1.00 & \\
\hline Fragmentation & 0.021 & 0.017 & 1.00 \\
\hline
\end{tabular}

Note: $*$ significant at $10 \%, * *$ significant at $3 \%, * * *$ significant at $1 \%$. 
Table 3: Licensing expenditures

\begin{tabular}{|l|c|c|c|}
\hline & $(1)$ & $(2)$ & $(3)$ \\
\hline Fragmentation & $\begin{array}{c}\text { Tobit } \\
\text { Lic./sal. } \geq 0\end{array}$ & Probit & $\begin{array}{c}\text { Tobit } \\
\text { Lic./sal. }>0\end{array}$ \\
& $2.26^{* *}$ & $1.05^{* *}$ & 0.64 \\
R\&D/sales & $(1.03)$ & $(0.53)$ & $(0.98)$ \\
Patent stock of firm/employees & $0.008^{* *}$ & 0.002 & $0.017^{* * *}$ \\
& $(0.004)$ & $(0.002)$ & $(0.005)$ \\
Log employees & 0.107 & 0.10 & 0.187 \\
& $(0.159)$ & $(0.08)$ & $(0.207)$ \\
Log patents at technoloy level & $0.057^{* * *}$ & $0.06 * * *$ & $-0.13^{* * *}$ \\
& $(0.020)$ & $(0.01)$ & $(0.02)$ \\
Herfindahl index & -0.044 & -0.01 & $-0.08^{* *}$ \\
Index patent protection & $(0.043)$ & $(0.02)$ & $(0.04)$ \\
& -0.0005 & $0.0003 *$ & 0.0001 \\
Log age of firm & $(0.0004)$ & $(0.0002)$ & $(0.0003)$ \\
& $0.126 *$ & $0.08 * *$ & -0.05 \\
Dummy Eastern Germany & $(0.067)$ & $(0.03)$ & $(0.06)$ \\
& 0.005 & 0.005 & -0.02 \\
Observations & $(0.018)$ & $(0.009)$ & $(0.02)$ \\
Log likelihood & -0.089 & -0.050 & 0.10 \\
& $(0.065)$ & $(0.030)$ & $(0.06)$ \\
\hline
\end{tabular}

Note: The dependent variable in column 1 is a dummy for positive licensing expenditures. The dependent variable in columns 2 and 3 is licensing expenditures/sales. Year and industry dummies included. Standard errors in parentheses. * significant at $10 \%,{ }^{* *}$ significant at $3 \%$, *** significant at $1 \%$. 
Table 4: Tobit estimation: product innovation

\begin{tabular}{|c|c|c|c|c|c|c|c|}
\hline & $(1)$ & $(2)$ & (3) & $(4)$ & $(5)$ & $(6)$ & $(7)$ \\
\hline & All firms & Licensees & $\begin{array}{c}\text { Non- } \\
\text { licensees }\end{array}$ & $\begin{array}{l}\text { Licensees, } \\
\text { patents }<5\end{array}$ & $\begin{array}{l}\text { Licensees, } \\
\text { patents } \geq 5\end{array}$ & $\begin{array}{c}\text { Non- } \\
\text { licensees, } \\
\text { patents }<5\end{array}$ & $\begin{array}{c}\text { Non- } \\
\text { licensees, } \\
\text { patents } \geq 5\end{array}$ \\
\hline Fragmentation & $\begin{array}{l}62.45^{*} \\
(33.22)\end{array}$ & $\begin{array}{c}-138.2^{* *} \\
(70.32)\end{array}$ & $\begin{array}{c}103.67 * * * \\
(38.16)\end{array}$ & $\begin{array}{l}-217.69^{*} \\
(127.15)\end{array}$ & $\begin{array}{c}-144.25^{*} \\
(78.18)\end{array}$ & $\begin{array}{l}69.09^{*} \\
(56.06)\end{array}$ & $\begin{array}{c}118.30^{* *} \\
(50.24)\end{array}$ \\
\hline Innovation exp./employees & $\begin{array}{l}1.15^{* * *} \\
(0.096)\end{array}$ & $\begin{array}{c}0.414 * * \\
(0.183)\end{array}$ & $\begin{array}{l}1.35 * * * \\
(0.135)\end{array}$ & $\begin{array}{l}0.649 * \\
(0.343)\end{array}$ & $\begin{array}{l}0.601 * \\
(0.369)\end{array}$ & $\begin{array}{c}1.72 * * * \\
(0.19)\end{array}$ & $\begin{array}{l}1.00 * * * \\
(0.145)\end{array}$ \\
\hline Inno. exp./emp. squared & $\begin{array}{c}-0.005 * * * \\
(0.001)\end{array}$ & $\begin{array}{l}-0.001 \\
(0.001)\end{array}$ & $\begin{array}{c}-0.007 * * * \\
(0.001)\end{array}$ & $\begin{array}{l}-0.002 * \\
(0.002)\end{array}$ & $\begin{array}{c}-0.013 * \\
(0.009)\end{array}$ & $\begin{array}{c}-0.010 * * * \\
(0.002)\end{array}$ & $\begin{array}{c}-0.004 * * * \\
(0.001)\end{array}$ \\
\hline Log patent stock of firm & $\begin{array}{l}1.94 * * * \\
(0.677)\end{array}$ & $\begin{array}{l}0.178 \\
(1.21)\end{array}$ & $\begin{array}{c}2.58 * * * \\
(0.813)\end{array}$ & $\begin{array}{c}0.197^{*} \\
(7.25)\end{array}$ & $\begin{array}{c}-1.048^{*} \\
(1.47)\end{array}$ & $\begin{array}{l}1.46^{*} \\
(3.21)\end{array}$ & $\begin{array}{l}2.35^{*} \\
(1.55)\end{array}$ \\
\hline Log patents at tech. level & $\begin{array}{l}0.653 \\
(1.34)\end{array}$ & $\begin{array}{l}4.40 * \\
(2.57)\end{array}$ & $\begin{array}{l}-0.813 \\
(1.57)\end{array}$ & $\begin{array}{l}7.53^{*} \\
(4.80)\end{array}$ & $\begin{array}{l}2.29 * \\
(2.67)\end{array}$ & $\begin{array}{c}-1.35^{*} \\
(2.28)\end{array}$ & $\begin{array}{c}-0.883 * \\
(2.13)\end{array}$ \\
\hline Herfindahl index & $\begin{array}{l}-0.003 \\
(0.012)\end{array}$ & $\begin{array}{c}0.022 \\
(0.023)\end{array}$ & $\begin{array}{l}-0.012 \\
(0.014)\end{array}$ & $\begin{array}{l}0.050^{*} \\
(0.039)\end{array}$ & $\begin{array}{l}0.036^{*} \\
(0.031)\end{array}$ & $\begin{array}{l}-0.019 * \\
(0.018)\end{array}$ & $\begin{array}{l}-0.004 * \\
(0.021)\end{array}$ \\
\hline Index patent protection & $\begin{array}{l}3.52 * \\
(2.14)\end{array}$ & $\begin{array}{c}7.00 \\
(4.46)\end{array}$ & $\begin{array}{c}1.67 \\
(2.48)\end{array}$ & $\begin{array}{l}3.81 * \\
(9.77)\end{array}$ & $\begin{array}{c}11.89 * * \\
(4.65)\end{array}$ & $\begin{array}{l}-0.97 * \\
(3.29)\end{array}$ & $\begin{array}{l}3.19^{*} \\
(3.94)\end{array}$ \\
\hline Log employees & $\begin{array}{c}-1.37 * * \\
(0.632)\end{array}$ & $\begin{array}{c}-2.68 * * \\
(1.31)\end{array}$ & $\begin{array}{c}-1.42 * * \\
(0.726)\end{array}$ & $\begin{array}{c}-4.262^{*} \\
(2.44)\end{array}$ & $\begin{array}{c}-0.771 * \\
(1.35)\end{array}$ & $\begin{array}{l}-2.04 * * \\
(0.938)\end{array}$ & $\begin{array}{c}0.626^{*} \\
(1.18)\end{array}$ \\
\hline Log age of firm & $\begin{array}{l}-0.307 \\
(0.586)\end{array}$ & $\begin{array}{l}0.016 \\
(1.15)\end{array}$ & $\begin{array}{l}-0.352 \\
(0.683)\end{array}$ & $\begin{array}{l}0.364^{*} \\
(2.513)\end{array}$ & $\begin{array}{l}0.388^{*} \\
(0.999)\end{array}$ & $\begin{array}{c}0.019^{*} \\
(1.01)\end{array}$ & $\begin{array}{l}-1.56^{*} \\
(0.916)\end{array}$ \\
\hline Dummy Eastern Germany & $\begin{array}{c}-1.48 \\
(1.93) \\
\end{array}$ & $\begin{array}{l}0.038 \\
(4.19) \\
\end{array}$ & $\begin{array}{l}-1.74 \\
(2.19) \\
\end{array}$ & $\begin{array}{l}2.614 * \\
(7.569)\end{array}$ & $\begin{array}{l}-5.61 * \\
(4.65) \\
\end{array}$ & $\begin{array}{l}-2.16^{*} \\
(2.78) \\
\end{array}$ & $\begin{array}{c}-1.34^{*} \\
(3.70)\end{array}$ \\
\hline $\begin{array}{l}\text { Observations } \\
\text { Log likelihood }\end{array}$ & $\begin{array}{c}1343 \\
-3683.55\end{array}$ & $\begin{array}{c}288 \\
-958.03\end{array}$ & $\begin{array}{c}1055 \\
-2698.15\end{array}$ & $\begin{array}{c}133 \\
-427.60\end{array}$ & $\begin{array}{c}155 \\
-497.60\end{array}$ & $\begin{array}{c}606 \\
-1403.67\end{array}$ & $\begin{array}{c}449 \\
-1263.88\end{array}$ \\
\hline
\end{tabular}

Note: The dependent variable is share of sales from products new to the market. Year and industry dummies included. Standard errors in parentheses. ${ }^{*}$ significant at $10 \%, * *$ significant at $3 \%, * * *$ significant at $1 \%$. 
Table 5: Tobit estimation: process innovation

\begin{tabular}{|l|c|c|c|}
\hline & $(1)$ & $(2)$ & $(3)$ \\
\hline & All firms & Licensees & Non-licensees \\
\hline Fragmentation & $34.39^{*}$ & 16.14 & $42.212^{* *}$ \\
Innovation exp./employees & $(18.46)$ & $(39.13)$ & $(21.380)$ \\
& $0.474^{* * *}$ & $0.309^{* * *}$ & $0.594^{* * *}$ \\
Inno. exp./employees squared & $(0.058)$ & $(0.116)$ & $(0.084)$ \\
& $-0.002^{* * *}$ & $-0.001^{*}$ & $-0.004^{* * *}$ \\
Log patent stock of firm & $(0.0004)$ & $(0.001)$ & $(0.001)$ \\
& $0.873^{* *}$ & 0.742 & $0.925^{* *}$ \\
Log patents at technoloy level & $(0.382)$ & $(0.681)$ & $(0.466)$ \\
& -0.096 & -0.890 & 0.093 \\
Herfindahl index & $(0.802)$ & $(1.635)$ & $(0.926)$ \\
& 0.004 & -0.014 & 0.011 \\
Index patent protection & $(0.006)$ & $(0.015)$ & $(0.008)$ \\
& -0.301 & $-5.202^{* *}$ & 0.774 \\
Log employees & $(1.18)$ & $(2.426)$ & $(1.379)$ \\
& $2.06^{* * *}$ & $1.556^{*}$ & $2.000^{* * *}$ \\
Log age of firm & $(0.389)$ & 0.868 & 0.451 \\
& -0.006 & 0.926 & -0.335 \\
Dummy Eastern Germany & $(0.319)$ & $(0.649)$ & $(0.373)$ \\
& -1.86 & 0.985 & $-2.706^{*}$ \\
Observations & $(1.20)$ & $(2.645)$ & $(1.390)$ \\
Log likelihood & 1237 & 261 & 976 \\
\end{tabular}

Note: The dependent variable is percentage of cost reduction due to process innovations. Year and industry dummies included. Standard errors in parentheses. * significant at $10 \%$, ** significant at $3 \%, * * *$ significant at $1 \%$. 
Table 6: Tobit estimation: evidence on inventing around

\begin{tabular}{|l|c|c|c|}
\hline & $(1)$ & $(2)$ & $(3)$ \\
\hline Fragmentation & All Firms & Licensees & Non-Licensees \\
& $99.362^{* * *}$ & -8.792 & $125.502^{* * *}$ \\
Fragmentation X & $(35.781)$ & $(78.188)$ & $(41.636)$ \\
Innovation expenditure & $-3.271^{* * *}$ & $-6.996^{* * *}$ & -2.329 \\
Innovation exp./employees & $(1.168)$ & $(2.257)$ & $(1.745)$ \\
& $3.580^{* * *}$ & $5.433^{* *}$ & $3.056^{* *}$ \\
Inno. exp./employees squared & $(0.883)$ & $(1.638)$ & $(1.295)$ \\
& $-0.006^{* * *}$ & $-0.002^{*}$ & $-0.007^{* * *}$ \\
Log patent stock of firm & $(0.001)$ & $(0.001)$ & $(0.001)$ \\
& $1.929^{* * *}$ & 0.045 & $2.612^{* * *}$ \\
Log patents at technology level & $(0.674)$ & $(1.176)$ & $(0.812)$ \\
& 0.552 & 3.253 & -0.774 \\
Herfindahl index & $(1.340)$ & $(2.509)$ & $(1.564)$ \\
& -0.002 & 0.026 & -0.012 \\
Index patent protection & $(0.012)$ & $(0.022)$ & $(0.014)$ \\
& 3.387 & 6.001 & 1.688 \\
Log employees & $(2.130)$ & $(4.317)$ & $(2.478)$ \\
& $-1.345^{* *}$ & $-2.314^{*}$ & $-1.453^{* *}$ \\
Log age of firm & $(0.630)$ & $(1.277)$ & $(0.725)$ \\
& -0.313 & 0.153 & -0.371 \\
Dummy Eastern Germany & $(0.585)$ & $(1.113)$ & $(0.683)$ \\
& -1.566 & 1.738 & -1.928 \\
& $(1.927)$ & $(4.091)$ & $(2.191)$ \\
\hline Observations & 1343 & 288 & 1055 \\
Log likelihood & -3679.76 & -952.16 & -2697.30 \\
\hline
\end{tabular}

Note: The dependent variable is share of sales from products new to the market. Year and industry dummies included. Standard errors in parentheses. * significant at $10 \%, * *$ significant at $3 \%,{ }^{* *}$ significant at $1 \%$. 


\section{References}

Anand, B., Khanna, T. (2000), "Do Firms Learn to Create Value? The Case of Alliances", Strategic Management Journal, 21, 295-315.

Arora, A., Fosfuri, A. and Gambardella, A. (2001), "Markets for Technology: Economics of Innovation and Corporate Strategy", MIT Press, Cambridge MA.

Bessen, J. (2004), "Holdup and Licensing of Cumulative Innovations With Private Information", Economics Letters, 82, 321-326.

Bessen, J. and Hunt, R. (2007), “An Empirical Look at Software Patents", Journal of Economics and Management Strategy, 16, 157-89.

Bessen, J. and Maskin, E. (2000), "Sequential Innovation, Patents, and Imitation”, MIT Department of Economics, Working Paper No. 00-01 (forthcoming RAND Journal of Economics).

Cassiman, B. and Veugelers, R. (2000), "External Technology Sources: Embodied or Disembodied Technology Acquisition.”, University Pompeu Fabra, Economics and Business Working Paper No. 444.

Clark, D. and Konrad, K. (2008), "Fragmented property rights and Incentives for R\&D”, Management Science, 54, 969-981.

Cockburn, I. and MacGarvie, M. (2007), "Patents, Thickets and the Financing of Early Stage Firms: Evidence from the Software Industry”, NBER Working Paper No. 13644.

Czarnitzki, D. and Kraft, K. (2005), "License Expenditures of Incumbents and Potential Entrants: An Empirical Analysis of Firm Behavior", ZEW Discussion Paper No. 05-35.

Galasso, A. and Schankerman, M. (2008), "Patent Thickets and the Market for Ideas: Evidence from Settlement of Patent Disputes", mimeo.

Gallini, N. T. (2002), "The Economics of Patents: Lessons from Recent U.S. Patent Reform” The Journal of Economic Perspectives, 16, 131-154.

Gans, J., Hsu, D. and Stern, S. (2002), "When Does Start-Up Innovation Spur the Gale of Creative Destruction?", RAND Journal of Economics, 33, 571-586.

Gans J. and Stern S. (2003), "When Does Funding Research by Smaller Firms Bear Fruit? Evidence from the SBIR Program", Economics of Innovation and New Technology, 12, 361-384.

Gerardin D., Layne-Farrar A. and Padilla A. J. (2007), "Royalty Stacking in High Tech Industries: Separating Myth from Reality”, CEPR Discussion Paper No. 6091. 
Von Graevenitz, G. and Siebert, R. (2006), "How Licensing Resolves Hold-Up: Evidence from a Dynamic Panel with Unobserved Heterogeneity", CEPR Discussion Paper 5436.

Von Graevenitz, G., Wagner, S. and Harhoff, D. (2008), Incidence and Growth of Patent Thickets - The Impact of Technological Opportunities and Complexity, CEPR Discussion Paper No. 6900.

Green, J. R. and Scotchmer, S. (1995), "On the Division of Profit in Sequential Innovation", RAND Journal of Economics, 26, 20-33.

Hall, B. H. (2005), "Exploring the Patent Explosion”, Journal of Technology Transfer, 30, 3548.

Häussler, C., Harhoff, D. and Müller, E. (2008), “To Be Financed or Not - The Role of Patents for Venture Capital Financing”, Working Paper.

Heller, M. A. and Eisenberg, R. S. (1998), "Can Patents Deter Innovation? The Anti-commons in Biomedical Research", Science, 280, 698-701.

Lemley, M. and Shapiro, C. (2007), "Patent Holdup and Royalty Stacking", Texas Law Review, 85.

Lichtman, D. (2006), "Patent Holdouts in the Standard-Setting Process", Academic Advisory Council Bulletin 1.3, Progress and Freedom Foundation.

Link, A. and Scott, J. (2003), "U.S. Science Parks: the Diffusion of an Innovation and its Effects on the Academic Missions of Universities", International Journal of Industrial Organization, 21, 1323-1356.

Merges, R. P. and R. R. Nelson (1990), "On the Complex Economics of Patent Scope”, Columbia Law Review, 90, 839-916.

Nagaoko, S. (2008), "An Analysis of Unilateral and Cross-licensing: New Evidence from the Inventor Survey in Japan”, Working Paper.

Noel, M. and Schankerman, M. (2006), "Patent Thickets and Software Innovation: Theory and Evidence from a Panel of U.S. Firms", CEPR Working Paper No. 5701.

OECD (1994), "Using Patent Data as Science and Technological Indicators”, Patent Manual.

OECD and Eurostat (1997), "Oslo Manual - Proposed Guidelines for Collecting and Interpreting Technological Innovation Data", OECD/Eurostat, Paris.

Razgaitis, R. (2006), “U.S./Canadian Licensing In 2005-Survey Results”, les Nouvelles, 234245. 
Scotchmer, S. (1991), "Standing on the Shoulders of Giants: Cumulative Research and the Patent Law", Journal of Economic Perspectives, 5, 29-41.

Shapiro, C. (2001), "Navigating the Patent Thicket: Cross-licenses, Patent Pools, and StandardSetting", In: Jaffe, A., Lerner, J. and Stern, S. (eds.), Innovation Policy and the Economy, Vol. 1. MIT Press for the National Bureau of Economic Research.

Ziedonis, R. (2004), “Don't Fence Me In: Fragmented Markets for Technology and the Patent Acquisition Strategies of Firms", Management Science, 50, 804-820. 